\title{
The quality of genetic counselling in osteogenesis imperfecta
}

\author{
C. R. PATERSON \\ D.M., M.R.C.Path.
}

Elizabeth Mowat

M.B., M.R.C.G.P.

University Department of Biochemical Medicine, Ninewells Hospital and Medical School, Dundee DD1 9SY

\section{Summary}

A survey is reported of the genetic advice given to $\mathbf{2 7 2}$ families with osteogenesis imperfecta. An appreciable number of families were not given advice by anyone even though they had asked for it, and only one quarter of the families had been referred to a clinical genetic specialist. Overall approximately one third of the information recollected as having been received was incorrect but genetic specialists were clearly more successful than other doctors.

\section{Introduction}

Osteogenesis imperfecta (OI) is by far the most common heritable disorder of bone and has a frequency in Western countries of the order of 1 in 20000 (Sillence, Senn and Danks, 1979; Smith, Francis and Bauze, 1975). It is not a single disease but consists of at least five distinct disorders inherited both in autosomal dominant and in autosomal recessive manners. The dominant disease not infrequently arises as a result of a new mutation (Sillence et al., 1979).

Many affected families seek advice about genetic matters and this survey of the advice given to 272 such families in the British Isles is now reported.

\section{Patients and methods}

A questionnaire sent out to members of the Brittle Bone Society included questions on the severity of the disorder, family history and the other clinical features. Further questions asked whether genetic advice had been sought, what advice had been received and from whom. The response rate was $96 \%$. The members of the Brittle Bone Society may be to some extent a self-selected group but there was no evidence that families joined the society because of dissatisfaction with genetic advice. In 131 of the families the affected individuals had been seen personally by C.R.P.

Seventy-nine cases had a family history of OI and could readily be classified into types 1 or 4 of the Sillence classification (Sillence et al., 1979). Most were relatively mildly affected and had little or no disturbance of growth; 193 cases were from families with no previous history of the disorder; 70 patientso had clinical features similar to those seen in the dominantly-inherited disorders; 66 had the features. of classical osteogenesis imperfecta congenita (Sillence type 3) with multiple fractures at birth and poof growth in infancy; 57 cases were of intermediate severity and could not readily be classified into eithe $\overrightarrow{5}$ group.

Of the 272 OI families who took part in the survey, 196 reported having received some positive advice $=$ many on more than one occasion or on more thate one question (for example, in a sporadic case, the chance of further children being affected, the chasge of the affected person having affected children a the chance of unaffected siblings having affected children). In all, 291 different items were recorded in 246 of these it was possible to identify the specialo ity of the advising doctor.

\section{Results}

Table 1 shows the advice recollected as having been received by affected people who are memberș of families with clear evidence of dominant in heritance. In such a case, each child has a 1 in chance of being affected. In 17 cases the prospective parents understood that each child had a 1 in chance of being affected, but in 19 cases the advice given was clearly incorrect. In 6 cases the prospective parents were apparently simply advised to avoid

TABLE 1. Families with clear evidence of dominant inheritance: advice recollected as having been given to an affected person on the chance of his/her children being affected

\begin{tabular}{|c|c|}
\hline $\begin{array}{l}80-100 \% \\
1 \text { in } 2 \\
1 \text { in } 4 \\
66 \% \\
\text { Very unlikely } \\
\text { Hereditary disorder but no chances given } \\
\text { Only daughters would be affected } \\
\text { Only sons would be affected } \\
\text { The disorder would skip one generation } \\
\text { The more children you have the worse they'll be } \\
\text { The disorder gets worse with each generation }\end{array}$ & $\begin{array}{r}7 \\
17 \\
2 \\
1 \\
3 \\
8 \\
1 \\
2 \\
1 \\
2 \\
1\end{array}$ \\
\hline Total & 45 \\
\hline
\end{tabular}


pregnancy or to seek sterilization. In 9 families advice was sought but no clear answer given.

The issues are also relatively simple in the case of a clearly unaffected member of a family with dominantly inherited OI. Only 2 such people sought advice in this survey; in both cases they were told, correctly, that the chance of having an affected child was very small.

A much more common and difficult problem arises when OI occurs without a family history and the parents want to know how likely they are to have a further affected child. Such cases could arise as a result of recessive inheritance or as a result of a new mutation. In the individual case, it may be difficult to determine which of these possibilities applies but where the patient is clinically like the patients with dominant OI, new mutation is likely and recurrence is very unlikely; where the patient has classical severe OI congenita (Sillence type 3) the likelihood of recessive inheritance is high. However, there are appreciable numbers of cases in which neither clinical description applies. Table 2 shows the advice received in each of these groups. Twentysix families with classical OI congenita were told that recurrence was most unlikely. In 13, further pregnancies occurred; from a total of 18 pregnancies, 11 normal children, 4 affected children and 3 spontaneous abortions resulted.

TABLE 2. Osteogenesis imperfecta with no family history: advice recollected as having been given to parents of an affected child on the chance of further children being affected

\begin{tabular}{lccc}
\hline & $\begin{array}{c}\text { Probably } \\
\text { new } \\
\text { mutation } \\
\text { of } \\
\text { Advice }\end{array}$ & $\begin{array}{c}\text { dominant } \\
\text { disease }\end{array}$ & $\begin{array}{c}\text { Probably } \\
\text { recessive } \\
\text { disorder }\end{array} \begin{array}{c}\text { Variety } \\
\text { of OI } \\
\text { not clear }\end{array}$ \\
\hline Risk more than 1 in 2 & 1 & 2 & 1 \\
1 in 2 & - & 2 & 2 \\
1 in 4 & - & 6 & 3 \\
1 in 10 to 1 in 50 & - & 3 & 1 \\
Substantial risk & 1 & - & 2 \\
Possible but unlikely & 2 & 5 & 4 \\
Most unlikely & 8 & 26 & 8 \\
Likely (especially males) & - & 1 & - \\
A female could be affected & 1 & - & - \\
$\quad$ Total & 13 & 45 & 21 \\
\hline
\end{tabular}

Table 2 does not include 6 families in these groups in which the parents were not told about risk but simply advised not to have further children. In 2 cases parents were told to wait one to 5 years before having further children. In 2 families, conflicting advice was received from various doctors. In the sporadic cases where the patient cannot readily be allocated to one or other of the clinical subgroups mentioned it is probably reasonable to cite an empirical recurrence rate of perhaps $3 \%$ (Young and Harper, 1980). The authors know of only 2 families with affected siblings and unaffected parents in which the disorder was not classical OI congenita.

A similar problem arises when an affected individual without a family history seeks advice about his or her chance of having an affected child. If such a person has a recessively inherited form of the disease the chance of children being affected is negligible provided the spouse is not a relative. If the affected person represents a new mutation of the dominant disorder the chance for each child is 1 in 2 . Table 3 shows the advice recollected as having been given in these 2 subgroups and also in cases which could not be classified in either way. There is no clear difference in the types of advice given in the 2 very different clinical situations. In this group, 14 patients had sought advice but had not obtained any.

TABLE 3. No family history of the disorder: advice recollected as having been given to an affected person on the chance of passing on the disorder

\begin{tabular}{|c|c|c|c|}
\hline & $\begin{array}{c}\text { Probably } \\
\text { new } \\
\text { mutation } \\
\text { of } \\
\text { dominant } \\
\text { disease }\end{array}$ & $\begin{array}{l}\text { Probably } \\
\text { recessive } \\
\text { disorder }\end{array}$ & $\begin{array}{c}\text { Variety } \\
\text { of OI } \\
\text { not clear }\end{array}$ \\
\hline \multicolumn{4}{|l|}{ Very likely, $100 \%$, almost } \\
\hline 1 in 2 & 7 & 4 & 3 \\
\hline 1 in 4 & 2 & - & 1 \\
\hline 1 in 15 & - & - & 1 \\
\hline Children might be affected & 5 & 4 & 5 \\
\hline $\begin{array}{l}\text { not hereditary } \\
\text { More likely to pass on if } \\
\text { he/she married an }\end{array}$ & 8 & 6 & 3 \\
\hline $\begin{array}{l}\text { affected person } \\
\text { Not passed on from male } \\
50 \% \text { chance of mild disease; } \\
50 \% \text { chance of severe }\end{array}$ & $\begin{array}{l}1 \\
1\end{array}$ & $\overline{-}$ & 2 \\
\hline disease & - & - & 1 \\
\hline $\begin{array}{l}\text { got to start somewhere' } \\
\text { It might be several } \\
\text { generations before the } \\
\text { condition appears again }\end{array}$ & - & 1 & - \\
\hline Likely to be affected but less & & & \\
\hline severely & - & 1 & - \\
\hline Total & 31 & 25 & 20 \\
\hline
\end{tabular}

The last problem to consider is that of the clearly unaffected sibling of a sporadic case of OI. Whether new mutation or recessive inheritance is responsible, one can be confident that a normal sibling's children have a negligible chance of being affected. This question was asked on 12 occasions; on 9 the enquirer was rightly reassured.

On 243 occasions it was possible to identify the speciality of the advising doctor and the advice 
TABLE 4. Quality of genetic advice according to the speciality of the advising doctor.

Values in parentheses are percentages

\begin{tabular}{|c|c|c|c|c|}
\hline \multicolumn{5}{|c|}{ Quality of advice (as recollected by affected person) } \\
\hline & Clearly correct & Not unreasonable & Probably inaccurate & Total \\
\hline General practitioner & $\begin{array}{c}9 \\
(27)\end{array}$ & $\begin{array}{c}13 \\
(39)\end{array}$ & $\begin{array}{c}11 \\
(33)\end{array}$ & 33 \\
\hline Paediatrician & $\begin{array}{c}13 \\
(22)\end{array}$ & $\begin{array}{c}24 \\
(40)\end{array}$ & $\begin{array}{c}23 \\
(38)\end{array}$ & 60 \\
\hline Obstetrician & $\begin{array}{c}2 \\
(20)\end{array}$ & $\begin{array}{c}4 \\
(40)\end{array}$ & $\begin{array}{c}4 \\
(40)\end{array}$ & 10 \\
\hline Orthopaedic surgeon & $\begin{array}{c}9 \\
(17)\end{array}$ & $\begin{array}{c}24 \\
(45)\end{array}$ & $\begin{array}{c}20 \\
(38)\end{array}$ & 53 \\
\hline Genetic specialist & $\begin{array}{c}30 \\
(33)\end{array}$ & $\begin{array}{c}43 \\
(48)\end{array}$ & $\begin{array}{c}17 \\
(19)\end{array}$ & 90 \\
\hline Total & $\begin{array}{c}63 \\
(26)\end{array}$ & $\begin{array}{l}108 \\
(44)\end{array}$ & $\begin{array}{c}75 \\
(30)\end{array}$ & 246 \\
\hline
\end{tabular}

recollected as having been given was then classified according to its appropriateness and accuracy. The results are given in Table 4 . It is clear, although hardly surprising, that the performance of clinical genetic specialists is better than that of other doctors.

\section{Discussion}

The initial impression from the survey was that overall the quality of advice received by families with OI was unsatisfactory. It is possible that an appreciable proportion of the 'poor' answers represent occasions when good advice was badly recalled by the patient. It is well recognized that patients remember only part of the information they receive during a consultation (Ley and Spelman, 1965; Joyce et al., 1969). However, this cannot be the whole explanation since clinical genetic specialists were clearly more successful than other doctors. Furthermore, it could be argued that what matters is not what the doctor says but what the patient remembers.

There appeared to be 2 separate problems in the present group of patients who wanted genetic advice. Some who sought help did not receive it, and some received advice which was clearly inaccurate. Although all regions now have genetic advisory services of some sort and most have clinics staffed by consultant clinical geneticists (MRC/DHSS, 1980), these have not been used as fully as they might have been. Of the 272 families in the present study, 76 had received no advice at all. Of those who had, only 63 were referred to a clinical genetic specialist. The difficulty therefore, is not that good advice is not available, but that patients are not referred for it.

The problems of giving advice in osteogenesis imperfecta is compounded by the heterogeneity of the disorder and by the problem of variation in expressivity in some families (Sillence et al., 1979;
Paterson, 1980; Pope and Nicholls, 1980). Recents advances make it a little easier to give reliable advice provided the appropriate clinical featurest are taken into account. In a recent report of a jointo working party of the MRC and the DHSS (1980)음 recommendations are made that, for certain specialities such as ophthalmology, regional clinical geneti cists should be supported by national experts. Bone diseases are not mentioned in the working party'so report but this, too, is a field where there is a ne for consultants with special experience to advise at.a national level.

\section{Acknowledgments}

We are indebted to Dr M. Faed and to Professor G. H尺 Bell for their comments on the manuscript and to the members of the Brittle Bone Society, in particular its sec은 retary, Mrs Margaret Grant, for their help.

\section{References}

Joyce, C.R.B., Caple, G., Mason, M., Reynolds, E. \& MATTHEWS, J.A. (1969) Quantitative study of doctorpatient communication. Quarterly Journal of Medicine 2 . 38 (new series), 183.

Ley, P. \& Spelman, M.S. (1965) Communications in ap out-patient setting. British Journal of Social and Clinicą Psychology, 4, 114.

MRC/DHSS (1980) Joint Working Group on Genetic Coun? selling and Service Implications of Clinical Genetics. Medicat Research Council, London. PATERSON, C.R. (1980) Heterogeneity of osteogenesis imñ
perfecta congenita. Lancet, i, 820.

PoPe, F.M. \& NichOlLs, A.C. (1980) Heterogeneity of osteoß genesis imperfecta congenita. Lancet, i, 820.

Sillence, D.O., SenN, A. \& Danks, D.M. (1979) Genetič heterogeneity in osteogenesis imperfecta. Journal of Medica Genetics, 16, 101.

Smith, R., Francis, M.J.O. \& Bauze, R.J. (1975) Osteoe genesis imperfecta: a clinical and biochemical study of generalised connective tissue disorder. Quarterly Journat of Medicine (1980), 44 (new series), 555.

YOUNG, I.D. \& HARPER, P.S. (1980) Recurrence risk i osteogenesis imperfecta congenita. Lancet, i, 432. 